\title{
Microbial Transformation of Prenylquercetins by Mucor hiemalis
}

\author{
Fubo Han, Yina Xiao and Ik-Soo Lee * \\ College of Pharmacy, Chonnam National University, Gwangju 61186, Korea; hanfubo0306@gmail.com (F.H.); \\ yogurtxiao@163.com (Y.X.) \\ * Correspondence: islee@chonnam.ac.kr; Tel.: +82-62-530-2932
}

Academic Editor: Jane Ward

Received: 31 December 2019; Accepted: 23 January 2020; Published: 25 January 2020

\begin{abstract}
Quercetin, one of the most widely distributed flavonoids, has been found to show various biological activities including antioxidant, anticancer, and anti-inflammatory effects. It has been reported that bioactivity enhancement of flavonoids has often been closely associated with nuclear prenylation, as shown in 8-prenylquercetin and 5'-prenylquercetin. It has also been revealed in many studies that the biological activities of flavonoids could be improved after glucosylation. Three prenylated quercetins were prepared in this study, and microbial transformation was carried out in order to identify derivatives of prenylquercetins with increased water solubility and improved bioavailability. The fungus $M$. hiemalis was proved to be capable of converting prenylquercetins into more polar metabolites and was selected for preparative fermentation. Six novel glucosylated metabolites were obtained and their chemical structures were elucidated by NMR and mass spectrometric analyses. All the microbial metabolites showed improvement in water solubility.
\end{abstract}

Keywords: prenylquercetins; microbial transformation; biocatalysis; glucosylation; Mucor hiemalis

\section{Introduction}

Flavonoids, a large group of unique compounds that are widely distributed throughout the plant kingdom [1], have been reported to perform an essential role in some physiological courses and exhibited a variety of promising pharmaceutical properties for human health [2,3]. The activities of flavonoids are commonly associated with their antioxidant properties and capabilities of modulating the particular enzymes and cell receptors [4]. The antioxidant activity of Alpinia plants (Zingiberaceae family) has been reported to be influenced by the presence of flavonoids $[5,6]$.

Quercetin, one of the active flavonoid aglycones of Alpinia plants, is distributed in various vegetables and fruits [6,7]. It exhibits high and diverse biological activities such as anticancer, antibacterial, anti-inflammatory, and gastroprotective effects [7]. Prenylation increases the lipophilicity of flavonoids, which would increase their uptake through a higher affinity to semi-permeable membranes and thus improve the rate of absorption and bioavailability [8,9]. For example, 8-prenylquercetin (8-PQ) showed higher cellular uptake and lower efflux than quercetin in Caco-2 and $\mathrm{C} 2 \mathrm{C} 12$ myotube cells and enhanced the bioavailability of quercetin in different tissues in vivo [10]. 5 '-Prenylquercetin (uralenol) exhibited higher inhibitory effects against tyrosinase, PTP1B and $\alpha$-glucosidase enzymes, and the growth of hepatic stellate cells compared with those of quercetin [11-13]. The notion that the biological activities of quercetin were enhanced by prenylation led to the synthesis of 8-PQ (1) and other derivatives.

Although the biological properties of flavonoids are enhanced after prenylation, their potential applications are still limited by their poor solubility in aqueous solvents [14-16]. It has been demonstrated that glucosylation could significantly increase the water solubility of flavonoids and enhance their stability and bioavailability $[17,18]$. For instance, the quercetin glucosides were 
more efficiently absorbed than quercetin in the small intestine [19], and quercetin 3-O-glucoside showed stronger antiobesity effect than quercetin in a study with mice [20]. Xanthohumol $4^{\prime}-O-\beta$-D-glucopyranoside and xanthohumol $4^{\prime}-O-\beta-\mathrm{D}-\left(4^{\prime \prime \prime}-O\right.$-methyl $)$-glucopyranoside exhibited stronger antiproliferative activity against the human HT-29 colon cancer cell line than xanthohumol [21]. The cytotoxic activity of allolicoisoflavone B and semilicoisoflavone against HepG2 human hepatocellular cancer cell line was increased after glucosylation [22].

Although a number of chemical glucosylation strategies have been established, production of flavonoid glucosides by chemical synthesis is still a challenging, laborious work, and uneconomical at a large scale, since chemical synthesis requires protection-deprotection procedures, and harsh reaction conditions may cause the decomposition of aglycones [23-25]. Biological glucosylation methods provide alternative approaches for the structural modification of flavonoids. In recent years, the number of researches on the production of flavonoid glucosides from their aglycones by using microorganisms as biocatalysts has been increasing. These researches revealed that microbes could convert flavonoids to their corresponding $O$-glucosides in one step, allowing the preparation of sufficient amounts of $O$-glucosides for biological assays in a relatively short time [26-28].

It has been reported that phenolic glycosyltransferase was identified in the fungal strain Mucor hiemalis, exhibiting excellent capability of $O$-glucosylation of prenylated phenolic compounds [22]. It was further revealed in our previous investigations that $M$. hiemalis system could be an efficient glucosylation means for the prenylated flavonoids [29,30]. Thus, in the current study, biotransformation of the prenylated quercetins 1-3 was conducted by using $M$. hiemalis. Six novel glucosylated metabolites were obtained, and their chemical structures were elucidated by NMR and mass spectrometric analyses. All of the metabolites showed improved water solubility.

\section{Results and Discussions}

\subsection{Preparation and Microbial Biotransformation of Prenylquercetins}

Prenylquercetins were prepared by semi-synthetic method through nuclear prenylation of quercetin (Scheme 1), and 8-prenylquercetin $(8-\mathrm{PQ}, \mathbf{1})$ was obtained as the major product together with $6^{\prime}$-prenylquercetin $\left(6^{\prime}-\mathrm{PQ}, 2\right)$ and $8,6^{\prime}$-diprenylquercetin $\left(8,6^{\prime}\right.$-DPQ, 3$)$. Their structures were confirmed by NMR and MS data [31].
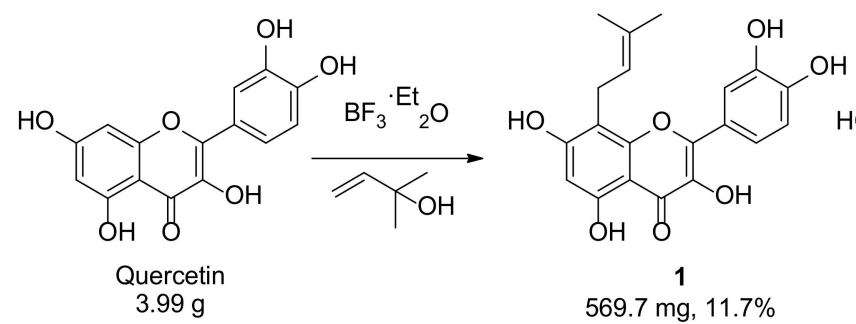

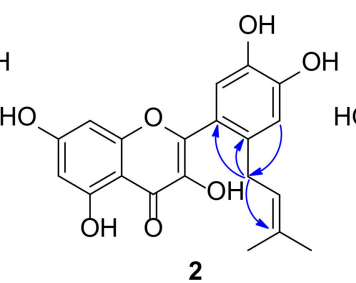

$246.5 \mathrm{mg}, 5.0 \%$

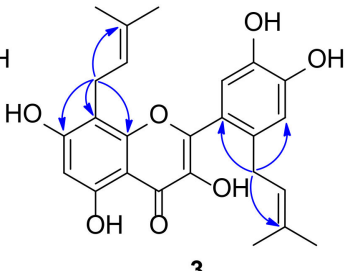

$172.41 \mathrm{mg}, 3.0 \%$

Scheme 1. Semi-synthesis of prenylquercetins. Selected HMBC correlations $\left({ }^{1} \mathrm{H} \rightarrow{ }^{13} \mathrm{C}\right)$ are indicated by arrows.

A total of 11 microbial cultures were screened for their ability to metabolize prenylquercetins 1-3, and the fungus M. hiemalis KCTC 26779 was selected for the scale-up fermentation studies (Supplementary Table S1). Substrate and culture control studies were carried out during the screening procedures, confirming that the metabolites were produced as a result of enzymatic activity by the fungus instead of a consequence of chemical or non-metabolic conversion.

\subsection{Structure Elucidation of Metabolites of Prenylquercetins}

The metabolites of 8-prenylquercetin (1), 6' -prenylquercetin (2), and 8,6'-diprenylquercetin (3) produced by $M$. hiemalis were isolated by column chromatography (Schemes $2-4$ ). 
High-resolution electrospray ionization mass spectral (HRESIMS) analysis of 4 showed a quasi-molecular ion peak $[\mathrm{M}+\mathrm{Na}]^{+}$at $\mathrm{m} / z 555.1479$ (calcd for $\mathrm{C}_{26} \mathrm{H}_{28} \mathrm{O}_{12} \mathrm{Na}$, 555.1478), which established the molecular formula of 4 as $\mathrm{C}_{26} \mathrm{H}_{28} \mathrm{O}_{12}$, indicating that it was a glycosylated derivative of 1 . Presence of the sugar moiety was also confirmed by the additional proton and carbon signals $\left(\delta_{\mathrm{H}}\right.$ 5.00 and 3.16-3.71 $\left.(6 \mathrm{H}) ; \delta_{C} 100.9,77.6,77.1,73.8,70.1,61.1\right)$ observed in the ${ }^{1} \mathrm{H}$ and ${ }^{13} \mathrm{C}$ NMR data of 4 . The sugar was assigned to be a glucopyranose on the basis of NMR data and by comparison of the TLC $R_{f}$ value with that of the D-glucose reference standard after acidic hydrolysis of 4 . The sugar was determined to be in $\beta$-configuration by the large coupling constant of $7.5 \mathrm{~Hz}$ of the anomeric proton signal at $\delta_{\mathrm{H}}$ 5.00. The significant downfield shift of the aromatic proton signal at $\delta_{\mathrm{H}} 6.60(\mathrm{H}-6)$ suggested that this sugar was attached to C-7 through an ether linkage. These spectral data were very similar to those of quercetin 7-O- $\beta$-D-glucopyranoside except for the appearance of the 8-prenyl group [32]. Thus, metabolite 4 was assigned as 8-prenylquercetin 7-O- $\beta$-D-glucopyranoside.

Compound 5 showed the $[\mathrm{M}+\mathrm{Na}]^{+}$peak at $\mathrm{m} / \mathrm{z} 555.1476$ (calcd for $\mathrm{C}_{26} \mathrm{H}_{28} \mathrm{O}_{12} \mathrm{Na}$, 555.1478), which established a molecular formula of $\mathrm{C}_{26} \mathrm{H}_{28} \mathrm{O}_{12}$, indicating that it was also a glycosylated derivative of 1 . Presence of the sugar moiety was confirmed by the additional proton and carbon signals $\left(\delta_{\mathrm{H}} 5.48\right.$ and 3.16-3.71 (6H); $\left.\delta_{C} 101.4,78.0,77.0,74.6,70.4,61.4\right)$ observed in the ${ }^{1} \mathrm{H}$ and ${ }^{13} \mathrm{C}$ NMR data of 5. The sugar was assigned to be a glucopyranose on the basis of NMR data and by comparison of the TLC $R_{f}$ value with that of the D-glucose reference standard after acidic hydrolysis of 5 . The sugar was determined to be in $\beta$-configuration by the large coupling constant of $7.2 \mathrm{~Hz}$ of the anomeric proton signal at $\delta_{\mathrm{H}} 5.48$. The upfield shift of the aromatic proton signal at $\delta_{\mathrm{H}} 7.64\left(\mathrm{H}-2^{\prime}\right)$ suggested that this sugar should be attached to $\mathrm{C}-3$ through an ether linkage. This was confirmed by the downfield chemical shift of C-2 at $\delta_{C} 156.5$ compared to 1 and the HMBC correlation between H-1"' and C-3 (Scheme 2). These spectral data were very similar to those of quercetin 3-O- $\beta$-D-glucopyranoside except for the appearance of the 8-prenyl group [32]. Thus, metabolite 5 was assigned as 8-prenylquercetin 3-O- $\beta$-D-glucopyranoside.

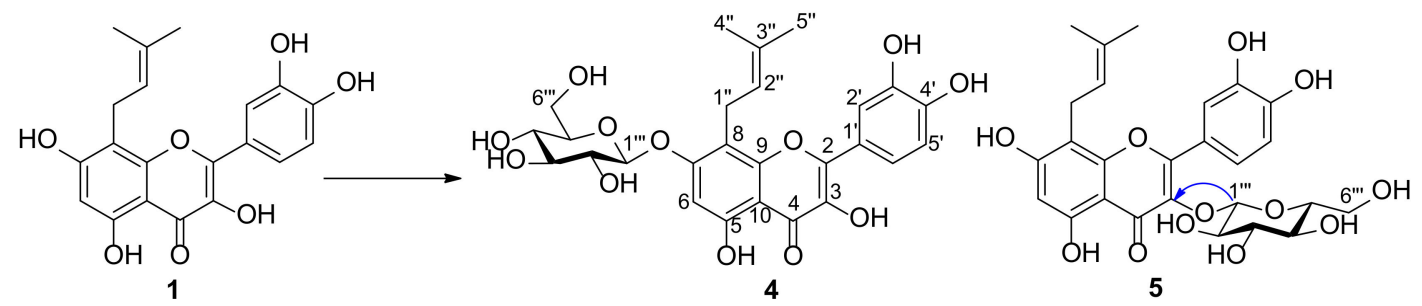

Scheme 2. Metabolites of 8-PQ (1) transformed by Mucor hiemalis. Selected HMBC correlations $\left({ }^{1} \mathrm{H} \rightarrow{ }^{13} \mathrm{C}\right)$ are indicated by arrows.

Compound 6 showed the $[\mathrm{M}+\mathrm{H}]^{+}$peak at $m / z 533.1656$ (calcd for $\mathrm{C}_{26} \mathrm{H}_{29} \mathrm{O}_{12}, 533.1659$ ), which established a molecular formula of $\mathrm{C}_{26} \mathrm{H}_{28} \mathrm{O}_{12}$, indicating that it was a glycosylated derivative of 2. Presence of the sugar moiety was confirmed by the additional proton and carbon signals $\left(\delta_{\mathrm{H}} 5.02\right.$ and 3.19-3.68 (6H); $\left.\delta_{C} 100.3,77.5,76.8,73.5,69.9,61.0\right)$ observed in the ${ }^{1} \mathrm{H}$ and ${ }^{13} \mathrm{C}$ NMR of 6 . The sugar was assigned to be a glucopyranose on the basis of NMR data and by comparison of the TLC $R_{f}$ value with that of the D-glucose reference standard after acidic hydrolysis of $\mathbf{6}$. The sugar was determined to be in $\beta$-configuration by the large coupling constant of $7.3 \mathrm{~Hz}$ of the anomeric proton signal at $\delta_{\mathrm{H}}$ 5.02. The downfield shift of the aromatic proton signal at $\delta_{\mathrm{H}} 6.65(\mathrm{H}-8)$ and $6.43(\mathrm{H}-6)$ suggested that this sugar should be attached to C-7 through an ether linkage. These spectral data were very similar to those of quercetin 7-O- $\beta$-D-glucopyranoside except for the appearance of the 6 '-prenyl group [32]. Thus, metabolite 6 was assigned as $6^{\prime}$-prenylquercetin 7-O- $\beta$-D-glucopyranoside.

Compound 7 showed the $[\mathrm{M}+\mathrm{Na}]^{+}$peak at $m / z 555.1477$ (calcd for $\mathrm{C}_{26} \mathrm{H}_{28} \mathrm{O}_{12} \mathrm{Na}$, 555.1478), which established a molecular formula of $\mathrm{C}_{26} \mathrm{H}_{28} \mathrm{O}_{12}$, indicating that it was also a glycosylated derivative of 2 . Presence of the sugar moiety was confirmed by the additional proton and carbon signals $\left(\delta_{\mathrm{H}} 4.72\right.$ and 3.19-3.66 $\left.(6 \mathrm{H}) ; \delta_{C} 102.2,77.7,76.5,73.7,70.1,61.0\right)$ observed in the ${ }^{1} \mathrm{H}$ and ${ }^{13} \mathrm{C}$ NMR of 7 . The sugar was assigned to be glucopyranose on the basis of NMR data and by comparison of the TLC $R_{f}$ value 
with that of the D-glucose reference standard after acidic hydrolysis of 7 . The sugar was determined to be in $\beta$-configuration by the large coupling constant of $7.3 \mathrm{~Hz}$ of the anomeric proton signal at $\delta_{\mathrm{H}}$ 4.72. The downfield shift of the aromatic proton signal at $\delta_{\mathrm{H}} 6.99\left(\mathrm{H}-5^{\prime}\right)$ suggested that this sugar should be attached to $\mathrm{C}-4^{\prime}$ through an ether linkage. It was further confirmed by HMBC correlation between $\mathrm{H}-1^{\prime \prime \prime}$ and $\mathrm{C}-4^{\prime}$ (Scheme 3 ). These spectral data were very similar to those of quercetin $4^{\prime}-O-\beta$-D-glucopyranoside except for the appearance of the $6^{\prime}$-prenyl group [32]. Thus, metabolite 7 was assigned as $6^{\prime}$-prenylquercetin $4^{\prime}-O-\beta$-D-glucopyranoside.<smiles>CC(C)=CCc1cc(O)c(O)cc1-c1oc2cc(O)cc(O)c2c(=O)c1O</smiles>

Scheme 3. Metabolites of 6'-PQ (2) transformed by Mucor hiemalis. Selected HMBC correlations $\left({ }^{1} \mathrm{H} \rightarrow{ }^{13} \mathrm{C}\right)$ are indicated by arrows.

Compound 8 showed the $[\mathrm{M}+\mathrm{Na}]^{+}$peak at $m / z 785.2631$ (calcd for $\mathrm{C}_{37} \mathrm{H}_{46} \mathrm{O}_{17} \mathrm{Na}$, 785.2633), which established a molecular formula of $\mathrm{C}_{37} \mathrm{H}_{46} \mathrm{O}_{17}$, indicating that it was a glycosylated derivative of 3, with two sugar moieties. Presence of the two sugar moieties was also confirmed by the additional proton and carbon signals $\left(\delta_{\mathrm{H}} 5.00,4.80\right.$ and $3.20-3.72(12 \mathrm{H}) ; \delta_{\mathrm{C}} 102.1,101.1,77.7,77.6,77.0,76.4$, 73.8, 73.7, 70.1, 70.1, 61.1, and 61.0) observed in the ${ }^{1} \mathrm{H}$ and ${ }^{13} \mathrm{C}$ NMR of 8. The two sugars were both assigned to be glucopyranose on the basis of NMR data and the TLC identification pattern of monosaccharides after acidic hydrolysis of $\mathbf{8}$. The sugars were determined to be in $\beta$-configuration by their large coupling constants of $7.2 \mathrm{~Hz}$ and $7.1 \mathrm{~Hz}$ of the anomeric proton signals at $\delta_{\mathrm{H}} 5.00$ and $\delta_{\mathrm{H}} 4.80$, respectively. The downfield shift of the aromatic proton signals at $\delta_{\mathrm{H}} 6.62(\mathrm{H}-6)$ and $\delta_{\mathrm{H}} 7.05$ $\left(\mathrm{H}-5^{\prime}\right)$ suggested that these two sugars should be attached to $\mathrm{C}-7$ and $\mathrm{C}-4^{\prime}$ through ether linkages, respectively. These connections were confirmed by HMBC correlations between $\mathrm{H}-1^{\prime \prime \prime \prime}$ and $\mathrm{C}-7$ as well as between $\mathrm{H}-1^{\prime \prime \prime \prime \prime}$ and $\mathrm{C}-4^{\prime}$ (Scheme 4). Thus, on the basis of these data, metabolite 8 was assigned as $8,6^{\prime}$-diprenylquercetin 7,4'-O- $\beta$-D-diglucopyranoside.

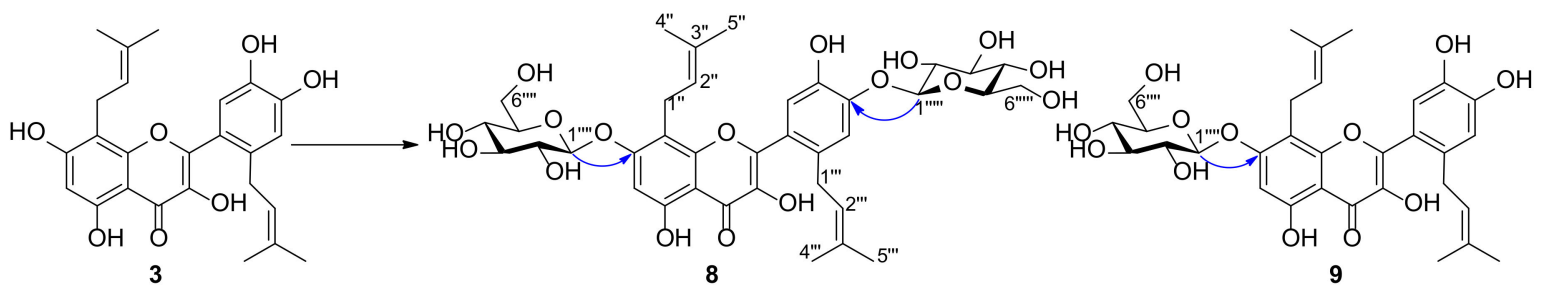

Scheme 4. Metabolites of 8,6'-DPQ (3) transformed by Mucor hiemalis. Selected HMBC correlations $\left({ }^{1} \mathrm{H} \rightarrow{ }^{13} \mathrm{C}\right)$ are indicated by arrows.

Compound 9 showed the $[\mathrm{M}+\mathrm{Na}]^{+}$peak at $\mathrm{m} / \mathrm{z} 623.2108$ (calcd for $\mathrm{C}_{31} \mathrm{H}_{36} \mathrm{O}_{12} \mathrm{Na} 623.2104$ ), which established a molecular formula of $\mathrm{C}_{31} \mathrm{H}_{36} \mathrm{O}_{12}$, indicating that it was a glycosylated derivative of 3 . The presence of the sugar moiety was also confirmed by the additional proton and carbon signals $\left(\delta_{\mathrm{H}} 5.00\right.$ and $\left.3.19-3.75(6 \mathrm{H}) ; \delta_{\mathrm{C}} 101.1,77.6,77.0,73.8,70.1,61.1\right)$ observed in the ${ }^{1} \mathrm{H}$ and ${ }^{13} \mathrm{C}$ NMR data of 9. The sugar was assigned to be glucopyranose on the basis of NMR data and by comparison of the TLC $R_{f}$ value with that of the D-glucose reference standard after acidic hydrolysis of $\mathbf{9}$. The sugar was identified as $\beta$-D-glucose by the large coupling constant of $7.3 \mathrm{~Hz}$ of the anomeric proton signal at $\delta_{\mathrm{H}}$ 5.00. The downfield shift of the aromatic proton signal at $\delta_{\mathrm{H}} 6.63(\mathrm{H}-6)$ suggested that this sugar should be attached to C-7 through an ether linkage. It was further confirmed by the HMBC 
correlation between $\mathrm{H}-1^{\prime \prime \prime \prime}$ and C-7 (Scheme 4). Thus, the structure of metabolite 9 was assigned as 8,6'-diprenylquercetin 7-O- $\beta$-D-glucopyranoside.

\subsection{Water Solubility of Prenylquercetins and Their Metabolites}

The water solubility of prenylquercetins and their metabolites was examined and summarized in Supplementary Table S2. It was observed that $6^{\prime}$-prenylation improved its water solubility (quercetin: $0.035 \mathrm{mg} / \mathrm{mL} ; 2: 0.063 \mathrm{mg} / \mathrm{mL}$ ). It was established that glucosylation could significantly enhance the water solubility of prenylquercetins by comparing the solubility of compounds 1-3 with their glucosides. Solubility was affected not only by the position that glucose was attached to, but also by the number of glucose units. In fact, metabolite 8 containing two glucose units showed higher solubility than metabolite $\mathbf{9}$, which contains one glucose unit.

\section{Materials and Methods}

\subsection{General Experimental Procedures}

The ${ }^{1} \mathrm{H}$ and ${ }^{13} \mathrm{C}$ NMR spectra were obtained in DMSO- $d_{6}$ on a Bruker Avance III HD 400 spectrometer at 400 and $100 \mathrm{MHz}$, respectively, using TMS as internal standard. The chemical shift values $(\delta)$ are reported in ppm units, and the coupling constants $(J)$ are in Hertz $(\mathrm{Hz})$. UV spectra were recorded on a Jasco V-530 spectrophotometer (Jasco, Tokyo, Japan). HRESIMS was performed on a Waters Synapt G2 QTOF mass spectrometer (Waters, Milford, MA, USA). TLC analyses were carried out on precoated silica gel $60 \mathrm{~F}_{254}$ plates (Merck, Darmstadt, Germany). The developing system used was $\mathrm{CHCl}_{3}: \mathrm{MeOH}$ solution, and visualization of TLC plates was performed under UV light (254 and $365 \mathrm{~nm}$ ) or performed with anisaldehyde- $\mathrm{H}_{2} \mathrm{SO}_{4}$ spray reagent. The adsorbent used for open column chromatography was silica gel 60-230 mesh. HPLC was performed on a Waters 1525 Binary HPLC pump (Waters Corp., Milford, MA, USA) connected to a Waters 996 Photodiode Array detector using Zorbax RX-C18 $(21.2 \times 250 \mathrm{~mm})$ and Waters Symmetry C18 $(4.6 \times 150 \mathrm{~mm})$ columns with HPLC-grade methanol and water.

\subsection{Chemicals and Ingredients}

Quercetin was purchased from Alfa Aesar (Haverhill, MA, USA). All of the ingredients used for microbial culture media, including dextrose, peptone, malt extract, and potato dextrose broth, were purchased from Becton, Dickinson and Co (Detroit, MI, USA).

Prenylquercetins 1-3 were semi-synthesized by nuclear prenylation of quercetin, which was similar to the method used for the preparation of prenylapigenins [29]. Briefly, to a stirred solution of quercetin $(3.99 \mathrm{~g}, 13.2 \mathrm{mmol})$ in dry dioxane, $\mathrm{BF}_{3}$-etherate $(3.52 \mathrm{~mL}, 27.8 \mathrm{mmol}, 2.1 \mathrm{eq}$.$) was gradually$ added at room temperature for $30 \mathrm{~min}$. Then a solution of 2-methyl-3-buten-2-ol $(2.77 \mathrm{~mL}, 26.5 \mathrm{mmol}$, 2.0 eq.) in dry dioxane was added, and the resulting solution was stirred for another $8 \mathrm{~h}$. After keeping at room temperature overnight, diethyl ether was added and then washed with water (three times). The remaining ethereal layer was evaporated to dryness to give an orange-red gum containing PQ. The reaction mixture was subjected to silica gel chromatography eluting with $n$-hexane-EtOAc gradient mixture $(10: 1 \rightarrow 1: 1)$ to obtain crude prenylquercetins. Then the crude material was purified by HPLC eluting with $\mathrm{MeOH}: \mathrm{H}_{2} \mathrm{O}$ at a flow rate of $4.0 \mathrm{~mL} / \mathrm{min}$ to obtain 8-PQ and related derivatives.

8-Prenylquercretin (8-PQ, 1), pale yellow powder; $\mathrm{UV} \lambda_{\max }(\mathrm{MeOH}) \mathrm{nm}: 259,377 ;{ }^{1} \mathrm{H}$ NMR (DMSO- $d_{6}$, $400 \mathrm{MHz}) \delta 12.44(1 \mathrm{H}, \mathrm{s}, 5-\mathrm{OH}), 10.70(1 \mathrm{H}, \mathrm{s}, 7-\mathrm{OH}), 9.64(1 \mathrm{H}, \mathrm{s}, 3-\mathrm{OH}), 9.32\left(1 \mathrm{H}, \mathrm{s}, 3^{\prime}-\mathrm{OH}\right), 9.32(1 \mathrm{H}, \mathrm{s}$, $\left.4^{\prime}-\mathrm{OH}\right), 7.74\left(1 \mathrm{H}, \mathrm{d}, J=2.1 \mathrm{~Hz}, \mathrm{H}-2^{\prime}\right), 7.55\left(1 \mathrm{H}, \mathrm{dd}, J=2.1,8.5 \mathrm{~Hz}, \mathrm{H}-6^{\prime}\right), 6.93\left(1 \mathrm{H}, \mathrm{d}, J=8.5 \mathrm{~Hz}, \mathrm{H}-5^{\prime}\right)$, $6.31(1 \mathrm{H}, \mathrm{s}, \mathrm{H}-6), 5.21\left(1 \mathrm{H}, \mathrm{t}, J=7.0 \mathrm{~Hz}, \mathrm{H}-2^{\prime \prime}\right), 3.46\left(2 \mathrm{H}, \mathrm{d}, J=7.0 \mathrm{~Hz}, \mathrm{H}-1^{\prime \prime}\right), 1.77\left(1 \mathrm{H}, \mathrm{s}, \mathrm{H}-4^{\prime \prime}\right), 1.65$ $\left(1 \mathrm{H}, \mathrm{s}, \mathrm{H}-5^{\prime \prime}\right) ;{ }^{13} \mathrm{C}$ NMR (DMSO- $\left.d_{6}, 100 \mathrm{MHz}\right) \delta 176.5(\mathrm{C}-4), 161.6$ (C-7), 158.7 (C-5), 153.8 (C-9), 148.1 (C-4'), 147.2 (C-2), $145.6\left(\mathrm{C}-3^{\prime}\right), 136.0(\mathrm{C}-3), 131.5\left(\mathrm{C}-3^{\prime \prime}\right), 123.0\left(\mathrm{C}-1^{\prime}\right), 122.8\left(\mathrm{C}-2^{\prime \prime}\right), 120.2\left(\mathrm{C}-6^{\prime}\right), 116.0$ (C-5'), $115.7\left(\mathrm{C}-2^{\prime}\right), 106.0(\mathrm{C}-8), 103.4(\mathrm{C}-10), 98.2(\mathrm{C}-6), 25.9\left(\mathrm{C}-4^{\prime \prime}\right), 21.7\left(\mathrm{C}-1^{\prime \prime}\right), 18.3\left(\mathrm{C}-5^{\prime \prime}\right)$. 
$6^{\prime}$-Prenylquercretin $\left(6^{\prime}-\mathrm{PQ}, 2\right)$, pale yellow powder; $\mathrm{UV} \lambda_{\max }(\mathrm{MeOH}) \mathrm{nm}: 255,349 ;{ }^{1} \mathrm{H}$ NMR (DMSO- $d_{6}$, $400 \mathrm{MHz}) \delta 12.54(1 \mathrm{H}, \mathrm{s}, 5-\mathrm{OH}), 10.76(1 \mathrm{H}, \mathrm{s}, 7-\mathrm{OH}), 9.31(1 \mathrm{H}, \mathrm{s}, 3-\mathrm{OH}), 9.04\left(1 \mathrm{H}, \mathrm{s}, 3^{\prime}-\mathrm{OH}\right), 8.93(1 \mathrm{H}$, s, 4'-OH), $6.87\left(1 \mathrm{H}, \mathrm{s}, \mathrm{H}-2^{\prime}\right), 6.70\left(1 \mathrm{H}, \mathrm{s}, \mathrm{H}-5^{\prime}\right), 6.32(1 \mathrm{H}, \mathrm{d}, J=2.0 \mathrm{~Hz}, \mathrm{H}-8), 6.21(1 \mathrm{H}, \mathrm{d}, J=2.0 \mathrm{~Hz}$, $\mathrm{H}-6), 5.13\left(1 \mathrm{H}, \mathrm{t}, J=7.2 \mathrm{~Hz}, \mathrm{H}-2^{\prime \prime}\right), 3.15\left(2 \mathrm{H}, \mathrm{d}, J=7.2 \mathrm{~Hz}, \mathrm{H}-1^{\prime \prime}\right), 1.59\left(1 \mathrm{H}, \mathrm{s}, \mathrm{H}-4^{\prime \prime}\right), 1.49\left(1 \mathrm{H}, \mathrm{s}, \mathrm{H}-5^{\prime \prime}\right)$; ${ }^{13} \mathrm{C}$ NMR (DMSO- $\left.d_{6}, 100 \mathrm{MHz}\right) \delta 176.7$ (C-4), 164.3 (C-7), 161.4 (C-5), 157.2 (C-9), 150.5 (C-2), 147.6 (C-4'),143.4 (C-3'), 136.8 (C-3), 132.7 (C-6'), $131.5\left(\mathrm{C}-3^{\prime \prime}\right), 124.0\left(\mathrm{C}-2^{\prime \prime}\right), 120.8\left(\mathrm{C}-1^{\prime}\right), 117.6\left(\mathrm{C}-5^{\prime}\right), 117.0$ (C-2'), 104.0 (C-10), 98.6 (C-6), 93.8 (C-8), $31.6\left(\mathrm{C}-1^{\prime \prime}\right), 25.8\left(\mathrm{C}-4^{\prime \prime}\right), 18.0\left(\mathrm{C}-5^{\prime \prime}\right)$; HRESIMS m/z: 393.0947 $[\mathrm{M}+\mathrm{Na}]^{+}$(calcd for $\mathrm{C}_{20} \mathrm{H}_{18} \mathrm{O}_{7} \mathrm{Na}, 393.0950$ ).

8,6'-Diprenylquercretin (8,6'-DPQ, 3), pale yellow powder; UV $\lambda_{\max }(\mathrm{MeOH}) \mathrm{nm}: 259,355 ;{ }^{1} \mathrm{H} \mathrm{NMR}$ (DMSO-d $\left.d_{6}, 400 \mathrm{MHz}\right) \delta 12.48(1 \mathrm{H}, \mathrm{s}, 5-\mathrm{OH}), 10.68(1 \mathrm{H}, \mathrm{s}, 7-\mathrm{OH}), 9.29(1 \mathrm{H}, \mathrm{s}, 3-\mathrm{OH}), 9.00\left(1 \mathrm{H}, \mathrm{s}, 3^{\prime}-\mathrm{OH}\right)$, $8.85\left(1 \mathrm{H}, \mathrm{s}, 4^{\prime}-\mathrm{OH}\right), 6.83\left(1 \mathrm{H}, \mathrm{s}, \mathrm{H}-2^{\prime}\right), 6.70\left(1 \mathrm{H}, \mathrm{s}, \mathrm{H}-5^{\prime}\right), 6.31(1 \mathrm{H}, \mathrm{s}, \mathrm{H}-6), 5.07(2 \mathrm{H}, \mathrm{t}, J=7.2 \mathrm{~Hz}$, $\left.\mathrm{H}-2^{\prime \prime}, 2^{\prime \prime \prime}\right), 3.26\left(2 \mathrm{H}, \mathrm{d}, J=7.2 \mathrm{~Hz}, \mathrm{H}-1^{\prime \prime}\right), 3.16\left(2 \mathrm{H}, \mathrm{d}, J=7.2 \mathrm{~Hz}, \mathrm{H}-1^{\prime \prime \prime}\right), 1.58\left(1 \mathrm{H}, \mathrm{s}, \mathrm{H}-4^{\prime \prime}\right), 1.53(1 \mathrm{H}, \mathrm{s}$,

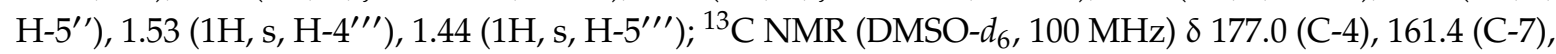
158.9 (C-5), 154.6 (C-9), 150.6 (C-2), 147.4 (C-4'), 143.4 (C-3'), 136.7 (C-3), 132.6 (C-6'), 131.5 (C-3'" $)$,

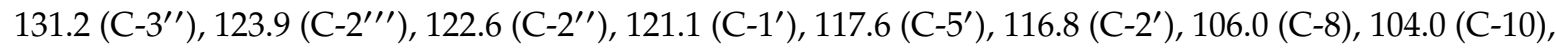
$98.2(\mathrm{C}-6), 31.6\left(\mathrm{C}-1^{\prime \prime \prime}\right), 25.9\left(\mathrm{C}-4^{\prime \prime}\right), 25.8\left(\mathrm{C}-4^{\prime \prime \prime}\right), 21.5\left(\mathrm{C}-1^{\prime \prime}\right), 17.9\left(\mathrm{C}-5^{\prime \prime}\right), 17.8\left(\mathrm{C}-5^{\prime \prime \prime}\right)$; HRESIMS m/z: $461.1566[\mathrm{M}+\mathrm{Na}]^{+}$(calcd for $\left.\mathrm{C}_{25} \mathrm{H}_{26} \mathrm{O}_{7} \mathrm{Na}, 461.1576\right)$.

\subsection{Microorganisms and Culture Media}

All the microorganisms were obtained from the Korean Collection for Type Cultures (KCTC). Eleven cultures were used for the preliminary screening procedure and are listed below: Absidia coerulea 6936, Alternaria alternata 6005, Aspergillus fumigatus 6145, Cunninghamella elegans var. elegans 6992, Fusarium merismoides 6153, Gliocladium deliquescens 6173, Glomerella cingulata 6075, Mortierella ramanniana var. angulispora 6137, Mucor hiemalis 26779, Penicillium chrysogenum 6933, Trichoderma koningii 6042. Stock cultures of fungi and other microorganisms were stored at $-60{ }^{\circ} \mathrm{C}$ with $20 \%$ glycerol.

Two types of media were used in the fermentation experiments and are listed below: A. alternata, A. coerulea, A. fumigatus, M. hiemalis, P. chrysogenum, and T. koningii were incubated on malt medium (malt extract $20 \mathrm{~g} / \mathrm{L}$, dextrose $20 \mathrm{~g} / \mathrm{L}$, and peptone $1 \mathrm{~g} / \mathrm{L}$ ). C. elegans var. elegans, F. merismoides, G. deliquescens, G. cingulata, and M. ramanniana var. angulispora were cultured on potato dextrose medium $(24 \mathrm{~g} / \mathrm{L})$.

\subsection{Procedure for Microbial Transformation}

Microbial transformation studies were carried out according to the standard two-stage procedure [33]. Briefly, the actively growing microbial cultures were incubated in $250 \mathrm{~mL}$ flasks containing $50 \mathrm{~mL}$ of media and incubated with gentle agitation $(200 \mathrm{rpm})$ at $25{ }^{\circ} \mathrm{C}$ in a temperature-controlled shaking incubator. The dimethyl sulfoxide solution $(10 \mathrm{mg} / \mathrm{mL})$ of each substrate was added to each flask at a concentration of $16 \mu \mathrm{g} / \mathrm{mL} 24 \mathrm{~h}$ after inoculation and incubated further under the same condition for 7 days. General sampling and TLC monitoring were performed on precoated TLC plates $\left(\mathrm{CHCl}_{3}: \mathrm{MeOH}\right)$ at an interval of $24 \mathrm{~h}$. UV $(254$ and $365 \mathrm{~nm})$ and anisaldehyde- $\mathrm{H}_{2} \mathrm{SO}_{4}$ reagent were used for the identification of metabolites. Culture controls consisted of fermentation cultures in which the microbes were grown without addition of substrates. Substrate controls consisted of substrates added to sterile culture media with no microbes added.

\subsection{Scale-up Fermentation and Isolation of Metabolites}

Preparative-scale fermentation was carried out under the same condition with five $1 \mathrm{~L}$ flasks each containing $200 \mathrm{~mL}$ medium and $15 \mathrm{mg} 8-\mathrm{PQ}, 14 \mathrm{mg} 6^{\prime}-\mathrm{PQ}$, and $11 \mathrm{mg} 8,6^{\prime}$-DPQ for 5 days, respectively. The cultures were extracted with EtOAc three times, and the organic layers were combined and concentrated under reduced pressure. The EtOAc extract $(270 \mathrm{mg})$ of 8-PQ (1) culture broth was subjected to reversed-phase HPLC using a gradient solvent system of $\mathrm{MeOH}: \mathrm{H}_{2} \mathrm{O}(40: 60 \rightarrow 60: 40)$ 
eluting at a flow rate of $4 \mathrm{~mL} / \mathrm{min}$ to obtain compounds $4\left(6.95 \mathrm{mg}, \mathrm{t}_{\mathrm{R}} 47.4 \mathrm{~min}\right)$ and $5(45.37 \mathrm{mg}$, $t_{R} 67.9 \mathrm{~min}$ ). The EtOAc extract (396 mg) of 6'-PQ (2) culture broth was subjected to reversed-phase HPLC using the same elution condition as above to obtain compounds 6 (5.89 $\mathrm{mg}, \mathrm{t}_{\mathrm{R}} 42.9 \mathrm{~min}$ ) and $7\left(15.72 \mathrm{mg}\right.$, $\left.\mathrm{t}_{\mathrm{R}} 56.2 \mathrm{~min}\right)$. Likewise, the EtOAc extract (360 mg) of 8,6'-DPQ (3) culture broth was subjected to reversed-phase HPLC to obtain compounds 8 (6.42 mg, $\left.\mathrm{t}_{\mathrm{R}} 40.3 \mathrm{~min}\right)$ and 9 (19.16 mg, $\left.t_{R} 58.6 \mathrm{~min}\right)$.

\subsection{Spectroscopic Data of Metabolites}

8-Prenylquercetin 7-O- $\beta$-D-glucopyranoside (4), pale yellow powder; $\mathrm{UV} \lambda_{\max }(\mathrm{MeOH}) \mathrm{nm}: 259,377 ;{ }^{1} \mathrm{H}$ NMR (DMSO- $\left.d_{6}, 400 \mathrm{MHz}\right) \delta 12.49(1 \mathrm{H}, \mathrm{s}, 5-\mathrm{OH}), 7.73\left(1 \mathrm{H}, \mathrm{d}, J=2.1 \mathrm{~Hz}, \mathrm{H}-2^{\prime}\right), 7.56(1 \mathrm{H}, \mathrm{dd}, J=2.1$, $\left.8.5 \mathrm{~Hz}, \mathrm{H}-6^{\prime}\right), 6.92\left(1 \mathrm{H}, \mathrm{d}, J=8.5 \mathrm{~Hz}, \mathrm{H}-5^{\prime}\right), 6.60(1 \mathrm{H}, \mathrm{s}, \mathrm{H}-6), 5.22\left(1 \mathrm{H}, \mathrm{t}, J=7.0 \mathrm{~Hz}, \mathrm{H}-2^{\prime \prime}\right), 5.00(1 \mathrm{H}$, $\left.\mathrm{d}, J=7.5 \mathrm{~Hz}, \mathrm{H}-\mathrm{1}^{\prime \prime \prime}\right), 3.73\left(1 \mathrm{H}, \mathrm{d}, J=11.8 \mathrm{~Hz}, \mathrm{H}-6^{\prime \prime \prime}\right), 3.49\left(1 \mathrm{H}, \mathrm{dd}, J=5.5,11.8 \mathrm{~Hz}, \mathrm{H}-6^{\prime \prime \prime}\right), 3.46$ $\left(2 \mathrm{H}, \mathrm{d}, J=7.0 \mathrm{~Hz}, \mathrm{H}-1^{\prime \prime}\right), 3.43\left(1 \mathrm{H}, \mathrm{m}, \mathrm{H}-5^{\prime \prime \prime}\right), 3.33\left(1 \mathrm{H}, \mathrm{m}, \mathrm{H}-3^{\prime \prime \prime}\right), 3.31\left(1 \mathrm{H}, \mathrm{m}, \mathrm{H}-2^{\prime \prime \prime}\right), 3.19(1 \mathrm{H}, \mathrm{m}$, $\left.\mathrm{H}-4^{\prime \prime \prime}\right), 1.78\left(1 \mathrm{H}, \mathrm{s}, \mathrm{H}-4^{\prime \prime}\right), 1.63\left(1 \mathrm{H}, \mathrm{s}, \mathrm{H}-5^{\prime \prime}\right) ;{ }^{13} \mathrm{C}$ NMR (DMSO-d $\left.6,100 \mathrm{MHz}\right) \delta 176.8$ (C-4), 160.5 (C-7), 159.0 (C-5), 153.0 (C-9), 148.4 (C-4'), 148.0 (C-2), 145.6 (C-3'), 136.3 (C-3), 131.6 (C-3"'), 122.8 (C-1'), $122.6\left(\mathrm{C}-2^{\prime \prime}\right), 120.5\left(\mathrm{C}-6^{\prime}\right), 116.1\left(\mathrm{C}-5^{\prime}\right), 115.7\left(\mathrm{C}-2^{\prime}\right), 108.4(\mathrm{C}-8), 104.8$ (C-10), $100.9\left(\mathrm{C}-1^{\prime \prime \prime}\right), 97.8$ (C-6), $77.6\left(\mathrm{C}-5^{\prime \prime \prime}\right), 77.1\left(\mathrm{C}-3^{\prime \prime \prime}\right), 73.8\left(\mathrm{C}-2^{\prime \prime \prime}\right), 70.1\left(\mathrm{C}-4^{\prime \prime \prime}\right), 61.1\left(\mathrm{C}-6^{\prime \prime \prime}\right), 26.0\left(\mathrm{C}-4^{\prime \prime}\right), 21.9\left(\mathrm{C}-1^{\prime \prime}\right), 18.4\left(\mathrm{C}-5^{\prime \prime}\right)$; HRESIMS $m / z: 555.1479[\mathrm{M}+\mathrm{Na}]^{+}$(calcd for $\mathrm{C}_{26} \mathrm{H}_{28} \mathrm{O}_{12} \mathrm{Na}$, 555.1478).

8-Prenylquercetin 3-O- $\beta$-D-glucopyranoside (5), pale yellow powder; $\mathrm{UV} \lambda_{\max }(\mathrm{MeOH}) \mathrm{nm}: 271,357 ;{ }^{1} \mathrm{H}$ NMR (DMSO- $\left.d_{6}, 400 \mathrm{MHz}\right) \delta 12.58(1 \mathrm{H}, \mathrm{s}, 5-\mathrm{OH}), 7.64\left(1 \mathrm{H}, \mathrm{d}, J=2.0 \mathrm{~Hz}, \mathrm{H}-2^{\prime}\right), 7.59(1 \mathrm{H}, \mathrm{dd}, J=2.0,8.4$ $\left.\mathrm{Hz}, \mathrm{H}-6^{\prime}\right), 6.87\left(1 \mathrm{H}, \mathrm{d}, J=8.4 \mathrm{~Hz}, \mathrm{H}-5^{\prime}\right), 6.31(1 \mathrm{H}, \mathrm{s}, \mathrm{H}-6), 5.48\left(1 \mathrm{H}, \mathrm{d}, J=7.2 \mathrm{~Hz}, \mathrm{H}-1^{\prime \prime \prime}\right), 5.17(1 \mathrm{H}, \mathrm{t}$, $\left.J=6.9 \mathrm{~Hz}, \mathrm{H}-2^{\prime \prime}\right), 3.60\left(1 \mathrm{H}, \mathrm{d}, J=11.5 \mathrm{~Hz}, \mathrm{H}-6^{\prime \prime \prime}\right), 3.42\left(2 \mathrm{H}, \mathrm{m}, \mathrm{H}-\mathrm{-}^{\prime \prime}\right), 3.36\left(1 \mathrm{H}, \mathrm{m}, \mathrm{H}-6^{\prime \prime \prime}\right), 3.26(2 \mathrm{H}$, $\left.\mathrm{m}, \mathrm{H}-2^{\prime \prime \prime}, 3^{\prime \prime \prime}\right), 3.11\left(1 \mathrm{H}, \mathrm{m}, \mathrm{H}-4^{\prime \prime \prime}, 5^{\prime \prime \prime}\right), 1.72\left(1 \mathrm{H}, \mathrm{s}, \mathrm{H}-4^{\prime \prime}\right), 1.64\left(1 \mathrm{H}, \mathrm{s}, \mathrm{H}-5^{\prime \prime}\right) ;{ }^{13} \mathrm{C}$ NMR (DMSO- $d_{6}$, $100 \mathrm{MHz}$ ) $\delta 178.2$ (C-4), 162.0 (C-7), 159.2 (C-5), 156.5 (C-2), 154.0 (C-9), 148.9 (C-4'), 145.3 (C-3'), 133.6 (C-3), $131.6\left(\mathrm{C}-3^{\prime \prime}\right), 122.8\left(\mathrm{C}-2^{\prime \prime}\right), 121.9\left(\mathrm{C}-1^{\prime}\right), 121.9\left(\mathrm{C}-6^{\prime}\right), 116.8\left(\mathrm{C}-2^{\prime}\right), 115.6\left(\mathrm{C}-5^{\prime}\right), 106.2(\mathrm{C}-8), 104.4$ (C-10), 101.4 (C-1'" $), 98.7(\mathrm{C}-6), 78.0\left(\mathrm{C}-5^{\prime \prime \prime}\right), 77.0\left(\mathrm{C}-3^{\prime \prime \prime}\right), 74.6\left(\mathrm{C}-2^{\prime \prime \prime}\right), 70.4\left(\mathrm{C}-4^{\prime \prime \prime}\right), 61.4\left(\mathrm{C}-6^{\prime \prime \prime}\right), 25.9$ $\left(\mathrm{C}-4^{\prime \prime}\right), 21.7\left(\mathrm{C}-1^{\prime \prime}\right), 18.3\left(\mathrm{C}-5^{\prime \prime}\right)$; HRESIMS m/z: $555.1476[\mathrm{M}+\mathrm{Na}]^{+}$(calcd for $\mathrm{C}_{26} \mathrm{H}_{28} \mathrm{O}_{12} \mathrm{Na}$, 555.1478).

$6^{\prime}$-Prenylquercetin 7-O- $\beta$-D-glucopyranoside (6), pale yellow powder; $\mathrm{UV} \lambda_{\max }(\mathrm{MeOH}) \mathrm{nm}: 253,350 ;{ }^{1} \mathrm{H}$ NMR (DMSO- $\left.d_{6}, 400 \mathrm{MHz}\right) \delta 12.49(1 \mathrm{H}, \mathrm{s}, 5-\mathrm{OH}), 6.88\left(1 \mathrm{H}, \mathrm{s}, \mathrm{H}-2^{\prime}\right), 6.69\left(1 \mathrm{H}, \mathrm{s}, \mathrm{H}-5^{\prime}\right), 6.65(1 \mathrm{H}, \mathrm{d}$, $J=2.1 \mathrm{~Hz}, \mathrm{H}-8), 6.43(1 \mathrm{H}, \mathrm{d}, J=2.1 \mathrm{~Hz}, \mathrm{H}-6), 5.12\left(1 \mathrm{H}, \mathrm{t}, J=7.3 \mathrm{~Hz}, \mathrm{H}-2^{\prime \prime}\right), 5.02(1 \mathrm{H}, \mathrm{d}, J=7.3 \mathrm{~Hz}$, $\left.\mathrm{H}-1^{\prime \prime \prime}\right), 3.68\left(1 \mathrm{H}, \mathrm{d}, J=11.5 \mathrm{~Hz}, \mathrm{H}-6^{\prime \prime \prime}\right), 3.47\left(1 \mathrm{H}, \mathrm{dd}, J=5.4,11.5 \mathrm{~Hz}, \mathrm{H}-6^{\prime \prime \prime}\right), 3.42\left(1 \mathrm{H}, \mathrm{m}, \mathrm{H}-5^{\prime \prime \prime}\right), 3.27$ $\left(2 \mathrm{H}, \mathrm{m}, \mathrm{H}-2^{\prime \prime \prime}, 3^{\prime \prime \prime}\right), 3.19\left(1 \mathrm{H}, \mathrm{m}, \mathrm{H}-4^{\prime \prime \prime}\right), 3.16\left(2 \mathrm{H}, \mathrm{d}, J=7.3 \mathrm{~Hz}, \mathrm{H}-1^{\prime \prime}\right), 1.57\left(1 \mathrm{H}, \mathrm{s}, \mathrm{H}-4^{\prime \prime}\right), 1.48(1 \mathrm{H}, \mathrm{s}$, H-5 ${ }^{\prime \prime}$ ); ${ }^{13}$ C NMR (DMSO- $d_{6}, 100$ MHz) $\delta 176.9$ (C-4), 163.1 (C-7), 161.0 (C-5), 156.8 (C-9), 151.3 (C-2), $147.7\left(\mathrm{C}-4^{\prime}\right), 143.4\left(\mathrm{C}-3^{\prime}\right), 137.3(\mathrm{C}-3), 132.7\left(\mathrm{C}-6^{\prime}\right), 131.6\left(\mathrm{C}-3^{\prime \prime}\right), 123.9\left(\mathrm{C}-2^{\prime \prime}\right), 120.6\left(\mathrm{C}-1^{\prime}\right), 117.6\left(\mathrm{C}-5^{\prime}\right)$, $117.0\left(\mathrm{C}-2^{\prime}\right), 105.6(\mathrm{C}-10), 100.3\left(\mathrm{C}-1^{\prime \prime \prime}\right), 99.2(\mathrm{C}-6), 94.6(\mathrm{C}-8), 77.5\left(\mathrm{C}-5^{\prime \prime \prime}\right), 76.8\left(\mathrm{C}-3^{\prime \prime \prime}\right), 73.5\left(\mathrm{C}-2^{\prime \prime \prime}\right)$, $69.9\left(\mathrm{C}-4^{\prime \prime \prime}\right), 61.0\left(\mathrm{C}-6^{\prime \prime \prime}\right), 31.6\left(\mathrm{C}-1^{\prime \prime}\right), 25.9\left(\mathrm{C}-4^{\prime \prime}\right), 18.0\left(\mathrm{C}-5^{\prime \prime}\right)$; HRESIMS m/z: $533.1656[\mathrm{M}+\mathrm{H}]^{+}$(calcd for $\mathrm{C}_{26} \mathrm{H}_{29} \mathrm{O}_{12}, 533.1659$ ).

$6^{\prime}$-Prenylquercetin $44^{\prime}-\mathrm{O}-\beta$-D-glucopyranoside (7), pale yellow powder; $\mathrm{UV} \lambda_{\max }(\mathrm{MeOH}) \mathrm{nm}: 254,345 ;{ }^{1} \mathrm{H}$ NMR (DMSO- $\left.d_{6}, 400 \mathrm{MHz}\right) \delta 12.42(1 \mathrm{H}, \mathrm{s}, 5-\mathrm{OH}), 6.99\left(1 \mathrm{H}, \mathrm{s}, \mathrm{H}-5^{\prime}\right), 6.86\left(1 \mathrm{H}, \mathrm{s}, \mathrm{H}-2^{\prime}\right), 6.25(1 \mathrm{H}, \mathrm{d}, J=2.0$ $\mathrm{Hz}, \mathrm{H}-8), 6.14(1 \mathrm{H}, \mathrm{d}, J=2.0 \mathrm{~Hz}, \mathrm{H}-6), 5.07\left(1 \mathrm{H}, \mathrm{t}, J=7.3 \mathrm{~Hz}, \mathrm{H}-2^{\prime \prime}\right), 4.72\left(1 \mathrm{H}, \mathrm{d}, J=7.3 \mathrm{~Hz}, \mathrm{H}-1^{\prime \prime \prime}\right), 3.66$ $\left(1 \mathrm{H}, \mathrm{d}, J=11.4 \mathrm{~Hz}, \mathrm{H}-6^{\prime \prime \prime}\right), 3.48\left(1 \mathrm{H}, \mathrm{dd}, J=5.0,11.4 \mathrm{~Hz}, \mathrm{H}-6^{\prime \prime \prime}\right), 3.27\left(1 \mathrm{H}, \mathrm{m}, \mathrm{H}-2^{\prime \prime \prime}, 3^{\prime \prime \prime}, 5^{\prime \prime \prime}\right), 3.19(1 \mathrm{H}$, m, H-4 $\left.{ }^{\prime \prime \prime}\right), 3.13\left(2 \mathrm{H}, \mathrm{d}, J=7.3 \mathrm{~Hz}, \mathrm{H}-1^{\prime \prime}\right), 1.49\left(1 \mathrm{H}, \mathrm{s}, \mathrm{H}-4^{\prime \prime}\right), 1.40\left(1 \mathrm{H}, \mathrm{s}, \mathrm{H}-5^{\prime \prime}\right) ;{ }^{13} \mathrm{C}$ NMR (DMSO- $d_{6}$, $100 \mathrm{MHz}) \delta 176.8$ (C-4), 164.5 (C-7), 161.4 (C-5), 157.2 (C-9), 149.7 (C-2), 147.0 (C-4'), 144.8 (C-3'), 137.0 (C-3), $132.7\left(\mathrm{C}-6^{\prime}\right), 131.7\left(\mathrm{C}-3^{\prime \prime}\right), 124.3\left(\mathrm{C}-1^{\prime}\right), 123.6\left(\mathrm{C}-2^{\prime \prime}\right), 117.8\left(\mathrm{C}-2^{\prime}\right), 117.7\left(\mathrm{C}-5^{\prime}\right), 104.0(\mathrm{C}-10), 102.2$ $\left(\mathrm{C}-1^{\prime \prime \prime}\right), 98.7(\mathrm{C}-6), 93.9(\mathrm{C}-8), 77.7\left(\mathrm{C}-5^{\prime \prime \prime}\right), 76.5\left(\mathrm{C}-3^{\prime \prime \prime}\right), 73.7\left(\mathrm{C}-2^{\prime \prime \prime}\right), 70.1\left(\mathrm{C}-4^{\prime \prime \prime}\right), 61.0\left(\mathrm{C}-6^{\prime \prime \prime}\right), 31.8$ $\left(\mathrm{C}-1^{\prime \prime}\right), 25.8\left(\mathrm{C}-4^{\prime \prime}\right), 18.0\left(\mathrm{C}-5^{\prime \prime}\right)$; HRESIMS m/z: $555.1477[\mathrm{M}+\mathrm{Na}]^{+}\left(\right.$calcd for $\left.\mathrm{C}_{26} \mathrm{H}_{28} \mathrm{O}_{12} \mathrm{Na}, 555.1478\right)$. 
8, $6^{\prime}$-Diprenylquercetin 7,4'-O- $\beta$-D-diglucopyranoside (8), pale yellow powder; $\mathrm{UV} \lambda_{\max }(\mathrm{MeOH}) \mathrm{nm}$ : 256 , 354; ${ }^{1} \mathrm{H}$ NMR (DMSO- $\left.d_{6}, 400 \mathrm{MHz}\right) \delta 12.49$ (1H, s, 5-OH), $9.13(1 \mathrm{H}, \mathrm{s}, 3-\mathrm{OH}), 8.78\left(1 \mathrm{H}, \mathrm{s}, 3^{\prime}-\mathrm{OH}\right), 7.05$ $\left(1 \mathrm{H}, \mathrm{s}, \mathrm{H}-5^{\prime}\right), 6.90\left(1 \mathrm{H}, \mathrm{s}, \mathrm{H}-2^{\prime}\right), 6.62(1 \mathrm{H}, \mathrm{s}, \mathrm{H}-6), 5.36\left(1 \mathrm{H}, \mathrm{s}, 2^{\prime \prime \prime \prime}-\mathrm{OH}\right), 5.15\left(2 \mathrm{H}, \mathrm{s}, 5^{\prime \prime \prime \prime}, 5^{\prime \prime \prime \prime \prime}-\mathrm{OH}\right)$, $5.10\left(2 \mathrm{H}, \mathrm{m}, \mathrm{H}-2^{\prime \prime}, 2^{\prime \prime \prime}\right), 5.00\left(1 \mathrm{H}, \mathrm{d}, J=7.2 \mathrm{~Hz}, \mathrm{H}-1^{\prime \prime \prime \prime}\right), 4.80\left(1 \mathrm{H}, \mathrm{d}, J=7.1 \mathrm{~Hz}, \mathrm{H}-1^{\prime \prime \prime \prime \prime}\right), 4.65(2 \mathrm{H}, \mathrm{br} \mathrm{s}$, $\left.6^{\prime \prime \prime \prime}, 6^{\prime \prime \prime \prime \prime}-\mathrm{OH}\right), 3.72\left(2 \mathrm{H}, \mathrm{m}, \mathrm{H}-6^{\prime \prime \prime \prime}, 6^{\prime \prime \prime \prime \prime}\right), 3.51\left(2 \mathrm{H}, \mathrm{m}, \mathrm{H}-6^{\prime \prime \prime \prime}, 6^{\prime \prime \prime \prime \prime}\right), 3.48\left(2 \mathrm{H}, \mathrm{m}, \mathrm{H}-\mathrm{1}^{\prime \prime}\right), 3.43(1 \mathrm{H}, \mathrm{m}$, $\left.\mathrm{H}-5^{\prime \prime \prime \prime}\right), 3.34\left(1 \mathrm{H}, \mathrm{m}, \mathrm{H}-5^{\prime \prime \prime \prime \prime}\right), 3.33\left(1 \mathrm{H}, \mathrm{m}, \mathrm{H}-2^{\prime \prime \prime \prime \prime}\right), 3.32\left(1 \mathrm{H}, \mathrm{m}, \mathrm{H}-4^{\prime \prime \prime \prime \prime}\right), 3.31\left(2 \mathrm{H}, \mathrm{m}, \mathrm{H}-3^{\prime \prime \prime \prime}, 3^{\prime \prime \prime \prime \prime}\right)$, $3.29\left(1 \mathrm{H}, \mathrm{m}, \mathrm{H}-2^{\prime \prime \prime \prime}\right), 3.21\left(2 \mathrm{H}, \mathrm{m}, \mathrm{H}-\mathrm{-}^{\prime \prime \prime}\right), 3.20\left(1 \mathrm{H}, \mathrm{m}, \mathrm{H}-4^{\prime \prime \prime \prime}\right), 1.57\left(1 \mathrm{H}, \mathrm{s}, \mathrm{H}-4^{\prime \prime}\right), 1.54\left(1 \mathrm{H}, \mathrm{s}, \mathrm{H}-5^{\prime \prime}\right)$, $1.50\left(1 \mathrm{H}, \mathrm{s}, \mathrm{H}-4^{\prime \prime \prime}\right), 1.40\left(1 \mathrm{H}, \mathrm{s}, \mathrm{H}-5^{\prime \prime \prime}{ }^{\prime \prime}\right) ;{ }^{13} \mathrm{C}$ NMR (DMSO-d $\left.d_{6}, 100 \mathrm{MHz}\right) \delta 177.3$ (C-4), 160.5 (C-7), 159.2 (C-5), 153.8 (C-9), 150.7 (C-2), 147.0 (C-4'), 144.8 (C-3'), 137.1 (C-3), 132.7 (C-6'), 131.8 (C-3'”'), 131.4 $\left(\mathrm{C}-3^{\prime \prime}\right), 124.3\left(\mathrm{C}-1^{\prime}\right), 123.6\left(\mathrm{C}-2^{\prime \prime \prime}\right), 122.4\left(\mathrm{C}-2^{\prime \prime}\right), 117.7$ (C-2'), 117.4 (C-5'), 108.5 (C-8), 105.5 (C-10), 102.1 $\left(\mathrm{C}-1^{\prime \prime \prime \prime \prime \prime}\right), 101.1\left(\mathrm{C}-1^{\prime \prime \prime \prime}\right), 97.9(\mathrm{C}-6), 77.7\left(\mathrm{C}-5^{\prime \prime \prime \prime \prime \prime}\right), 77.6\left(\mathrm{C}-5^{\prime \prime \prime \prime}\right), 77.0\left(\mathrm{C}-3^{\prime \prime \prime \prime}\right), 76.4\left(\mathrm{C}-3^{\prime \prime \prime \prime \prime}\right), 73.8\left(\mathrm{C}-2^{\prime \prime \prime \prime}\right)$, $73.7\left(\mathrm{C}-2^{\prime \prime \prime \prime \prime \prime}\right), 70.1\left(\mathrm{C}-4^{\prime \prime \prime \prime}, 4^{\prime \prime \prime \prime \prime}\right), 61.1\left(\mathrm{C}-6^{\prime \prime \prime \prime}\right), 61.0\left(\mathrm{C}-6^{\prime \prime \prime \prime \prime}\right), 31.6\left(\mathrm{C}-1^{\prime \prime \prime}\right), 25.9\left(\mathrm{C}-4^{\prime \prime}\right), 25.8\left(\mathrm{C}-4^{\prime \prime \prime}\right), 21.5$ (C-1"'), $18.0\left(\mathrm{C}-5^{\prime \prime}\right), 17.8\left(\mathrm{C}-5^{\prime \prime \prime}\right)$; HRESIMS m/z: $785.2631[\mathrm{M}+\mathrm{Na}]^{+}\left(\right.$calcd for $\left.\mathrm{C}_{37} \mathrm{H}_{46} \mathrm{O}_{17} \mathrm{Na}, 785.2633\right)$.

8,6'-Diprenylquercetin 7-O- $\beta$-D-glucopyranoside (9), pale yellow powder; UV $\lambda_{\max }(\mathrm{MeOH}) \mathrm{nm}$ : 256 , 356; ${ }^{1} \mathrm{H}$ NMR (DMSO- $\left.d_{6}, 400 \mathrm{MHz}\right) \delta 12.55(1 \mathrm{H}, \mathrm{s}, 5-\mathrm{OH}), 9.37(1 \mathrm{H}, \mathrm{s}, 3-\mathrm{OH}), 9.07\left(1 \mathrm{H}, \mathrm{s}, 3^{\prime} / 4^{\prime}-\mathrm{OH}\right)$, $6.85\left(1 \mathrm{H}, \mathrm{s}, \mathrm{H}-2^{\prime}\right), 6.71\left(1 \mathrm{H}, \mathrm{s}, \mathrm{H}-5^{\prime}\right), 6.63(1 \mathrm{H}, \mathrm{s}, \mathrm{H}-6), 5.11\left(2 \mathrm{H}, \mathrm{m}, \mathrm{H}-2^{\prime \prime} / 2^{\prime \prime \prime}\right), 5.38\left(1 \mathrm{H}, \mathrm{s}, 2^{\prime \prime \prime \prime}-\mathrm{OH}\right)$, $5.18\left(1 \mathrm{H}, \mathrm{s}, 5^{\prime \prime \prime \prime}-\mathrm{OH}\right), 5.00\left(1 \mathrm{H}, \mathrm{d}, J=7.3 \mathrm{~Hz}, \mathrm{H}-1^{\prime \prime \prime \prime}\right), 4.68\left(1 \mathrm{H}, \mathrm{br} \mathrm{s}, 6^{\prime \prime \prime \prime}-\mathrm{OH}\right), 3.75(1 \mathrm{H}, \mathrm{d}, J=10.2$

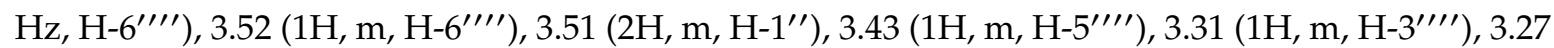
$\left(1 \mathrm{H}, \mathrm{m}, \mathrm{H}-2^{\prime \prime \prime \prime}\right), 3.19\left(1 \mathrm{H}, \mathrm{m}, \mathrm{H}-4^{\prime \prime \prime \prime}\right), 3.19\left(2 \mathrm{H}, \mathrm{m}, \mathrm{H}-1^{\prime \prime \prime}\right), 1.58\left(1 \mathrm{H}, \mathrm{s}, \mathrm{H}-4^{\prime \prime}\right), 1.55\left(1 \mathrm{H}, \mathrm{s}, \mathrm{H}-5^{\prime \prime}\right), 1.52$

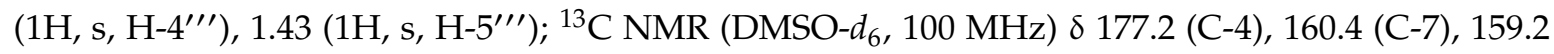
(C-5), 153.8 (C-9), 151.4 (C-2), 147.5 (C-4'), 143.4 (C-3'), 137.1 (C-3), 132.6 (C-6'), $131.5\left(\mathrm{C}-3^{\prime \prime \prime}\right), 131.4$ $\left(\mathrm{C}-3^{\prime \prime}\right), 123.9\left(\mathrm{C}-2^{\prime \prime \prime}\right), 122.5\left(\mathrm{C}-2^{\prime \prime}\right), 121.0\left(\mathrm{C}-1^{\prime}\right), 117.6\left(\mathrm{C}-2^{\prime}\right), 116.8\left(\mathrm{C}-5^{\prime}\right), 108.4(\mathrm{C}-8), 105.4(\mathrm{C}-10), 101.1$ $\left(\mathrm{C}-1^{\prime \prime \prime \prime}\right), 97.9(\mathrm{C}-6), 77.6\left(\mathrm{C}-5^{\prime \prime \prime \prime}\right), 77.0\left(\mathrm{C}-3^{\prime \prime \prime \prime}\right), 73.8\left(\mathrm{C}-2^{\prime \prime \prime \prime}\right), 70.1\left(\mathrm{C}-4^{\prime \prime \prime \prime}\right), 61.1\left(\mathrm{C}-6^{\prime \prime \prime \prime}\right), 31.6\left(\mathrm{C}-1^{\prime \prime \prime}\right)$, $26.0\left(\mathrm{C}-4^{\prime \prime}\right), 25.8\left(\mathrm{C}-4^{\prime \prime \prime}\right), 21.7\left(\mathrm{C}-1^{\prime \prime}\right), 17.9\left(\mathrm{C}-5^{\prime \prime}\right), 17.8\left(\mathrm{C}-5^{\prime \prime \prime}\right)$; HRESIMS m/z: $623.2108[\mathrm{M}+\mathrm{Na}]^{+}$ (calcd for $\mathrm{C}_{31} \mathrm{H}_{36} \mathrm{O}_{12} \mathrm{Na}$, 623.2104).

\subsection{Acid Hydrolysis}

Solutions of compounds 4-9 ( $1 \mathrm{mg}$ each) in $10 \% \mathrm{HCl}$ were heated at $80^{\circ} \mathrm{C}$ for $2 \mathrm{~h}$. After cooling, each mixture was neutralized and partitioned between EtOAc and $\mathrm{H}_{2} \mathrm{O}$. The water layer was concentrated to dryness and developed by silica gel TLC $\left(\mathrm{CHCl}_{3}: \mathrm{MeOH}: \mathrm{H}_{2} \mathrm{O}=13: 7: 2\right)$ in comparison with authentic D-glucose [34].

\subsection{Water Solubility Test}

The solubility of prenylquercetins and their glucosides were determined based on the previously reported method with some modifications $[35,36]$. Briefly, each compound $(4 \mathrm{mg})$ was dissolved in $1 \mathrm{~mL}$ of distilled water at room temperature followed by sonication for $10 \mathrm{~min}$ and centrifugation at $3600 \mathrm{rpm}$ for $5 \mathrm{~min}$ at room temperature. Then the concentrations of the compounds in the supernatant were measured based on their peak areas utilizing calibration curves determined by the HPLC of authentic samples.

\section{Conclusions}

8-PQ (1), 6'-PQ (2), and 8,6'-DPQ (3) were synthesized by nuclear prenylation method using $\mathrm{BF}_{3} \cdot \mathrm{Et}_{2} \mathrm{O}$ as catalyst. Six new glucosylated metabolites were furnished during the biotransformation studies with Mucor hiemalis. This and our previous studies [29,30] have shown that glucosylation of the flavonoids biocatalyzed by $M$. hiemalis took place at the hydroxyl group of the molecules. Glucosylation, however, strongly depended on the position of the hydroxyl group in prenylated flavonoids. For instance, existence of a hydroxyl group at C-3 position, if not sterically hindered, could significantly increase the transformation efficiency. And it was also revealed that $M$. hiemalis selectively catalyzed glucosylation of the hydroxyl group on the prenyl-substituted aromatic ring. To the best 
of our knowledge, few investigations have been reported on the glucosylation of prenylflavonoids by $M$. hiemalis, and this result may provide a new and valuable pathway to acquire prenylflavonoid glucosides. All the glucosylated metabolites increased the solubility in water compared with their aglycones, and an increase in the number of glucose units enhanced the aqueous solubility. Thus, our results suggest that prenylquercetin glucosides appear to be useful, and it may be necessary to conduct further studies for the evaluation of their biological activities.

Supplementary Materials: The following are available online. Figure S1-S26: 1D, 2D NMR spectra of compounds 1-9, Figure S27-S33: HRESIMS spectra of compounds 2-9, Table S1: Microbial screening results, Table S2: Water solubility of compounds 1-9.

Author Contributions: Conceptualization, I.-S.L.; Methodology, F.H. and I.-S.L.; Investigation, F.H., Y.X. and I.-S.L.; Resources, F.H.; Data curation, F.H. and Y.X.; Writing-original draft preparation, F.H.; Writing-review and editing, I.-S.L. and Y.X.; Supervision, I.-S.L.; Validation, F.H.; Project administration, I.-S.L.; Funding acquisition, F.H. All authors have read and agreed to the published version of the manuscript.

Funding: This research was supported by the Basic Science Research Program through the National Research Foundation of Korea (NRF), funded by the Ministry of Education (NRF-2019R1I1A1A01059410 awarded to F.H.).

Acknowledgments: The authors acknowledge Chonnam National University Center for Research Facilities for running NMR experiments and the Korea Basic Science Institute (KBSI) for running HRESIMS experiments.

Conflicts of Interest: The authors declare no conflict of interest.

\section{References}

1. Erlund, I. Review of the flavonoids quercetin, hesperetin, and naringenin. Dietary sources, bioactivities, bioavailability, and epidemiology. Nutr. Res. 2004, 24, 851-874. [CrossRef]

2. Lo Piero, A.R. The state of the art in biosynthesis of anthocyanins and its regulation in pigmented sweet oranges [(Citrus sinensis) L. Osbeck]. J. Agric. Food Chem. 2015, 63, 4031-4041. [CrossRef]

3. Ross, J.A.; Kasum, C.M. Dietary flavonoids: Bioavailability, metabolic effects, and safety. Annu. Rev. Nutr. 2002, 22, 19-34. [CrossRef] [PubMed]

4. Havsteen, B.H. The biochemistry and medical significance of the flavonoids. Pharmacol. Therapeut. 2002, 96, 67-202. [CrossRef]

5. Williams, C.A.; Harborne, J.B. The leaf flavonoids of the Zingiberales. Biochem. Syst. Ecol. 1977, 5, $221-229$. [CrossRef]

6. Mpalantinos, M.A.; Soares De Moura, R.; Parente, J.P.; Kuster, R.M. Biologically active flavonoids and kava pyrones from the aqueous extract of Alpinia Zerumbet. Phytother. Res. 1998, 12, 442-444. [CrossRef]

7. David, A.V.A.; Arulmoli, R.; Parasuraman, S. Overviews of biological importance of quercetin: A bioactive flavonoid. Pharmacogn. Rev. 2016, 10, 84-89.

8. Jelinek, L.; Karabin, M.; Kincl, T.; Hudcova, T.; Kotlikova, B.; Dostalek, P. Xanthohumol: Possible Isolation and Beer Enrichment. Chem. Listy 2013, 107, 209-213.

9. Yang, X.; Jiang, Y.; Yang, J.; He, J.; Sun, J.; Chen, F.; Zhang, M.; Yang, B. Prenylated flavonoids, promising nutraceuticals with impressive biological activities. Trends Food Sci. Technol. 2015, 44, 93-104. [CrossRef]

10. Mukai, R.; Fujikura, Y.; Murota, K.; Uehara, M.; Minekawa, S.; Matsui, N.; Kawamura, T.; Nemoto, H.; Terao, J. Prenylation enhances quercetin uptake and reduces efflux in Caco-2 cells and enhances tissue accumulation in mice fed long-term. J. Nutr. 2013, 143, 1558-1564. [CrossRef]

11. Zheng, Z.-P.; Cheng, K.-W.; Chao, J.; Wu, J.; Wang, M. Tyrosinase inhibitors from paper mulberry (Broussonetia papyrifera). Food Chem. 2008, 106, 529-535. [CrossRef]

12. Chen, R.M.; Hu, L.H.; An, T.Y.; Li, J.; Shen, Q. Natural PTP1B inhibitors from Broussonetia papyrifera. Bioorg. Med. Chem. Lett. 2002, 12, 3387-3390. [CrossRef]

13. Fan, Y.-H.; Ye, R.; Xu, H.-Y.; Feng, X.-H.; Ma, C.-M. Structures and in vitro antihepatic fibrosis activities of prenylated dihydrostilbenes and flavonoids from Glycyrrhiza uralensis Leaves. J. Food Sci. 2019, 84, 1124-1230. [CrossRef] [PubMed]

14. Tronina, T.; Strugała, P.; Popłoński, J.; Włoch, A.; Sordon, S.; Bartmańska, A.; Huszcza, E. The influence of glycosylation of natural and synthetic prenylated flavonoids on binding to human serum albumin and inhibition of cyclooxygenases COX-1 and COX-2. Molecules 2017, 22, 1230. [CrossRef] 
15. Kren, V.; Martínkovâ, I. Glycosides in medicine: "the role of glycosidic residue in biological activity". Curr. Med. Chem. 2001, 8, 1303-1328. [CrossRef]

16. Chebil, L.; Humeau, C.; Anthoni, J.; Dehez, F.; Engasser, J.-M.; Ghoul, M. Solubility of flavonoids in organic solvents. J. Chem. Eng. Data 2007, 52, 1552-1556. [CrossRef]

17. Murota, K.; Matsuda, N.; Kashino, Y.; Fujikura, Y.; Nakamura, T.; Kato, Y.; Shimiu, R.; Okuyama, S.; Tanaka, H.; Koda, T.; et al. $\alpha$-Oligoglucosylation of a sugar moiety enhances the bioavailability of quercetin glucosides in humans. Arch. Biochem. Biophys. 2010, 501, 91-97. [CrossRef]

18. Plaza, M.; Pozzo, T.; Liu, J.; Ara, K.Z.G.; Turner, C.; Karlsson, E.N. Substituent effects on in vitro antioxidizing properties, stability, and solubility in flavonoids. J. Agric. Food Chem. 2014, 62, 3321-3333. [CrossRef]

19. Brglez Mojzer, E.; Knez Hrnčič, M.; Škerget, M.; Knez, Ž.; Bren, U. Polyphenols: Extraction methods, antioxidative action, bioavailability and anticarcinogenic effects. Molecules 2016, 21, 901. [CrossRef]

20. Cao, H.; Xu, H.; Zhu, G.; Liu, S. Isoquercetin ameliorated hypoxia/reoxygenation-induced H9C2 cardiomyocyte apoptosis via a mitochondrial-dependent pathway. Biomed. Pharmacother. 2017, 95, 938-943. [CrossRef]

21. Tronina, T.; Bartmańska, A.; Milczarek, M.; Wietrzyk, J.; Popłoński, J.; Rój, E.; Huszcza, E. Antioxidant and antiproliferative activity of glycosides obtained by biotransformation of xanthohumol. Bioorg. Med. Chem. Lett. 2013, 23, 1957-1960. [CrossRef] [PubMed]

22. Ji, S.; Liang, W.-F.; Li, Z.-W.; Feng, J.; Wang, Q.; Qiao, X.; Ye, M. Efficient and selective glucosylation of prenylated phenolic compounds by Mucor hiemalis. RSC Adv. 2016, 6, 20791-20799. [CrossRef]

23. Zhu, X.; Schmidt, R.R. New principles for glycoside-bond formation. Angew. Chem. Int. Ed. Engl. 2009, 48, 1900-1934. [CrossRef] [PubMed]

24. Christensen, H.M.; Oscarson, S.; Jensen, H.H. Common side reaction of the glycosyl donor in chemical glycosylation. Carbohydr. Res. 2015, 408, 51-95. [CrossRef]

25. Semeniuchenko, V.; Garazd, Y.; Garazd, M.; Shokol, T.; Groth, U.; Khilya, V. Highly efficient glucosylation of flavonoids. Monatsh. Chem. 2009, 140, 1503-1512. [CrossRef]

26. Sordon, S.; Popłoński, J.; Huszcza, E. Microbial glycosylation of flavonoids. Pol. J. Microbiol. 2016, 65, 137-151. [CrossRef] [PubMed]

27. Sordon, S.; Popłoński, J.; Tronina, T.; Huszcza, E. Regioselective O-glycosylation of flavonoids by fungi Beauveria bassiana, Absidia coerulea and Absidia glauca. Bioorg. Chem. 2019, 93, 102750. [CrossRef] [PubMed]

28. Klingel, T.; Hadamjetz, M.; Fischer, A.; Wefers, D. Glycosylation of flavonoids and flavonoid glycosides by mutant dextransucrase from Lactobacillus reuteri TMW 1.106. Carbohydr. Res. 2019, 483, 107741. [CrossRef]

29. Xiao, Y.; Lee, I.-S. Microbial metabolism of prenylated apigenin derivatives by Mucor hiemalis. Phytochem. Lett. 2016, 16, 197-202. [CrossRef]

30. Xiao, Y.; Lee, I.-S. Microbial transformation of quercetin and its prenylated derivatives. Nat. Prod. Res. 2018, 32, 902-908. [CrossRef]

31. Kawamura, T.; Hayashi, M.; Mukai, R.; Terao, J.; Nemoto, H. An efficient method for C8-prenylation of flavonols and flavanones. Synthesis 2012, 44, 1308-1314.

32. Kajjout, M.; Rolando, C. Regiospecific synthesis of quercetin $O-\beta$-D-glucosylated and $O$ - $\beta$-D-glucuronidated isomers. Tetrahedron 2011, 67, 4731-4741. [CrossRef]

33. Clark, A.M.; Hufford, C.D. Use of microorganisms for the study of drug metabolism: An update. Med. Res. Rev. 1991, 11, 473-501. [CrossRef] [PubMed]

34. Han, F.; Lee, I.-S. A new flavonol glycoside from the aerial parts of Epimedium koreanum Nakai. Nat. Prod. Res. 2017, 31, 320-325. [CrossRef]

35. Kaminaga, Y.; Nagatsu, A.; Akiyama, T.; Sugimoto, N.; Yamazaki, T.; Maitani, T.; Mizukami, H. Production of unnatural glucosides of curcumin with drastically enhanced water solubility by cell suspension cultures of Catharanthus roseus. FEBS Lett. 2003, 555, 311-316. [CrossRef]

36. Lee, Y.-S.; Huh, J.-Y.; Nam, S.-H.; Kim, D.; Lee, S.-B. Synthesis of quercetin-3-O-glucoside from rutin by Penicillium decumbens naringinase. J. Food Sci. 2013, 78, C411-C415. [CrossRef]

Sample Availability: Samples of the compounds are available from the authors.

(C) 2020 by the authors. Licensee MDPI, Basel, Switzerland. This article is an open access article distributed under the terms and conditions of the Creative Commons Attribution (CC BY) license (http://creativecommons.org/licenses/by/4.0/). 